\title{
KAVRAMSAL SANAT YAPITLARINDA ANLAM: KOSUTH VE BEUYS ÖRNEĞİ
}

\section{Görkem Utku ALPARSLAN ${ }^{1}$}

Özet

Bu çalışmada, çağdaş sanat akımlarından kavramsal sanatın önemli iki temsilcisi Joseph Kosuth ve Joseph Beuys'un yapıtları Akademik ve Disiplinlerarası Yeni Sanat Eleştirisi Kuramı kullanılarak çözümlenmiştir. Söz konusu çözümlemelerin yapılmasındaki amaç kavramsal sanatın maddeden bağımsız yapısını ve zihinsel içeriğini örneklerle irdelemektir.

Çalışmada öncelikle kavramsal sanatın yapısı irdelenmiş; daha sonra iki eserin çözümlemesine geçilmiştir. İlk olarak Joseph Kosuth'un "Bir ve Üç Çekiç" adlı yapıtı ikinci olarak ise Joseph Beuys'un "Kötü Durum” adlı yapıtı çözümlenmiştir. Söz konusu çözümlemeler nesnel, akademik ve disiplinlerarası bir yöntemle yürütülmüştür. Ortaya çıkan sonuç; çağdaş sanatın önemli bir aşaması olan kavramsal sanatın zihinselliği, dil ile bağlantısı ve sorgulayıcı yönüdür.

Anahtar Kelimeler: Joseph Kosuth, Joseph Beuys, sanat eleştirisi

\section{MEANING IN CONCEPTUAL ART: CASE OF KOSUTH AND BEUYS}

\begin{abstract}
In this study, the works of Joseph Kosuth and Joseph Beuys, two important representatives of conceptual art from contemporary art movements, are analyzed by using Academic and Interdisciplinary New Art Criticism Theory. The purpose of the analysis is to examine the conceptual art's independent structure and mental content with examples.

In this study, first of all, the structure of conceptual art is examined; then two works were analyzed. First, Joseph Kosuth's "One and Three Hammers" and secondly, Joseph Beuys's Bad Situation, is analyzed. These analyzes were carried out in an objective, academic and interdisciplinary manner. The result; conceptual art, which is an important stage of contemporary art, is the mentality, connection with language and interrogator aspect.
\end{abstract}

Key Words: Joseph Kosuth, Joseph Beuys, art criticism

\section{GİRIŞ}

Çağdaş sanatın önemli bir aşaması olan kavramsal sanatın öncülerinden biri Marcel Duchamp'tır. Duchamp, sanatı sorgulayan ve bu sorgulama ekseninde yeni anlatım araçları arayan sanatçılardandı (Lynton, 2009, s.300). Duchamp'1n mirası sanatı maddesellikten kurtararak onu zihnin içinde oluşturulan bir yapıta çevirmiştir. Bu akımın önde gelen iki sanatçısı Joseph Kosuth ve Joseph Beuys'un birer yapıtı: Tayfun Akkaya'nın “Akademik ve Disiplinlerarası Yeni Sanat Eleştirisi Kuramı" ile çözümlenmiştir.

Akademik ve Disiplinlerarası Yeni Sanat Eleştirisi Kuramı; sekiz ana aşamadan ve yirmi iki alt başlıktan oluşmaktadır. Birinci Bölüm: Üç aşamalıdır, bu bölüm yapıtın döküm bilgilerinin verilmesi ve olgusal-anlatımsal anlam boyutunun tespitiyle ilgilidir. İkinci Bölüm:

\footnotetext{
${ }^{1}$ Dr. Öğr. Üyesi, Pamukkale Üniversitesi Eğitim Fakültesi Resim Eğitimi, e-posta: galparslan @ pau.edu.tr
} 
Dört aşamalıdır: $\mathrm{Bu}$ bölümde eserin konusu; varsa semboller, amblemler tespit edilmekte ve çözümlenmekte; atribüler 1şığında figürlerin kimlikleri belirlenmektedir. Üçüncü Bölüm: Beş aşamalıdır, bu bölümde konu ve anlatım elemanlarına dair tüm sanatsal ve estetik öğeler ele alınmaktadır. Dördüncü Bölüm: Kuramın ilk üç aşamasında yer alan analizlerin sentezlenerek, ana varsa yan temaların ortaya konulmasıdır. Beşinci Bölüm: Dört aşamalı olup karşılaştırmalar yoluyla sanatçının yaşamının-sanatsal yaratım faaliyetlerinin ve eserin özgün sanatsal niteliklerinin tespitine yöneliktir. Altıncı Bölüm: Beşinci bölümdeki nesnel tespitler temelinde dört aşamalı yargılama sürecidir. Yedinci Bölüm: Eserin sanat piyasasındaki yerine dair değerlendirmeye yöneliktir. Sekizinci Bölüm: eleştirilen esere dair ek açıklamaları ve tartışmaları içermektedir (Akkaya, 2014, ss. 95 - 96).

Akademik ve Disiplinlerarası Yeni Sanat Eleştirisi Kuramı kullanılarak yapılan bu çalışma; bu kuramın modern ve çağdaş sanata yapılan uyarlaması biçimindedir. Bu bağlamda bu çalışmada söz konusu uyarlamaya uymayan ya da karşılamayan alt başlıklar çıkarılmıştır.

\section{Kavramsal Sanata Bakış}

Bu iki sanatçı XX. yüzyıl sanatı içinde yer almaktadır. XX. yüzyıl sanatının ilk yarısı, izlenimcilik ile başlayan modern sanat anlayışının etkin olduğu bir dönemdir. 1980'li yılların ortalarına dek çağdaş sanatla modern sanat ayrışması keskin değildir (Danto'dan aktaran Erden, 2016, s. 314). Bu bağlamda kavramsal sanat ile modern sanatın yakın ilişki içinde olduğu savunulabilir.

Modernizm ile ilişkili olan modern resme değinmeden önce modernizm ile modern sanat arasındaki önemli bir ayrıntıya değinmekte yarar var: Modernizm ile modern sanat basitçe eşitlenemez. Modernizm, bir yandan modern sanat uygulamasıyla ilişkili fikir açısından bağımsız değerler yığınına, diğer yandan sanatta "modern"in eleştirel temsilinin belli bir biçimine karş1lık gelir (Harrison ve Wood, 2011, s. 22). Bu bağlamda; modern resmin "gelenekten kopuş" ilkesi temelinde bilimsel veriler ışığında, yer yer modern toplum yapısını eleştiren, gerçekliği yansıtma ilkesi çerçevesinde biçimlendiği söylenebilir.

Modern resmin sonu ise Arthur Danto'ya göre 1960'ların başlarında son bulmuştur. Pop sanat, minimalizm ve kavramsal sanat gibi akımlar modern resmin sonunu işaret eder (Danto, 2014, s. 116). Modern resmin sonu Kavramsal sanat olarak Danto tarafindan kabul edilse de; aralarındaki ilişki yadsınamaz. Modern resimde ortaya konan önemli bir fikir olan "zihinsel resim" kavramı Kavramsal sanatta tam olarak kendisini bulur. Kavramsal Sanat sanatın nesneye olan gereksinimini büyük ölçüde tartışmaya açmıştır. Düşünce ön plana geçmiş, yapıtın maddi varlığ 1 geride kalmıştır. Kavramsal sanatçılar, tekil nesneyi dışlayarak, düşünce merkezli olarak; belgeler, fotoğraflar, taslaklar, videolar vb. kullanmışlar ve sanatın geleneksel biçimini sorgulamışlardır (Antmen, 2006, ss. 193 - 194). Kavramsal sanatta resim sadece sanatçı için aşmayı istemediği bir sınıra dönüşür (Artan Oskay, 2018, s. 808). Amerikalı Joseph Kosuth "Felsefeden Sonra Sanat" başlıklı yazısında "kavramsal" terimini onaylayarak Duchamp'1 tarihi bir dönüm noktası olarak nitelemiştir. Ondan önce sanatın fiziksel somutluğu yüzünden engellendiği savını ortaya atmıştır (Hopkins, 2018, ss. 149 - 150). Kosuth'a göre “Kavramsal Sanatın en saf tanımı, kavram, sanatın temelini irdeleme olmalıdır". Kosuth, sanatı bir eğilim ya da bir biçem olarak görmenin, sanatın yalnızca biçimsel niteliklerini görme anlamına geldiğini 
ve sonuç bir nesne olsa bile sanatçının niyetinin ikinci plana atılacağını belirtmiştir. Mantıkçı bir yaklaşımla biçimselliğe önem vermeyen Kosuth, insanın estetiği sanattan ayırması gerektiğini savunarak, sanatçının daima sanatın doğasını sorgulayan insan olduğunu belirtmiştir (Atakan, 2015, ss. 55 - 56). Kosuth'a göre "organik biçimler geri dönülmez şekilde tükenmiştir". Sanat ancak kendisini bir dil olarak gördükçe, dolayısıyla her türlü biçimin gerisinde ve kavramın içinde yer aldıkça; kendi kendisini üretmeyi sürdürür (Eroğlu, 2015, s. 282). Joseph Beuys ise sanatın kültürel ve ideolojik gücünün ayırtına vararak; sanatın toplumsal eşitlik, aydınlanma ve emek kavgasına öncülük etmesi gerektiğini vurgulamıştır. Fluksus akımının kuramcılarından olan Beuys; sanatın kentsoyluların boyunduruğundan kurtulup halkın çıkarlarını savunan bir amaca yönelmesi gerekliliğin savunmuştur (Antmen, 2006, ss. 211 212). Bu bağlamda kavramsal sanatın ereğinin sanatı maddeden kurtararak izleyicinin zihninde oluşturmak olduğu ifade edilebilir.

\section{Yapıt Çözümlemeleri}

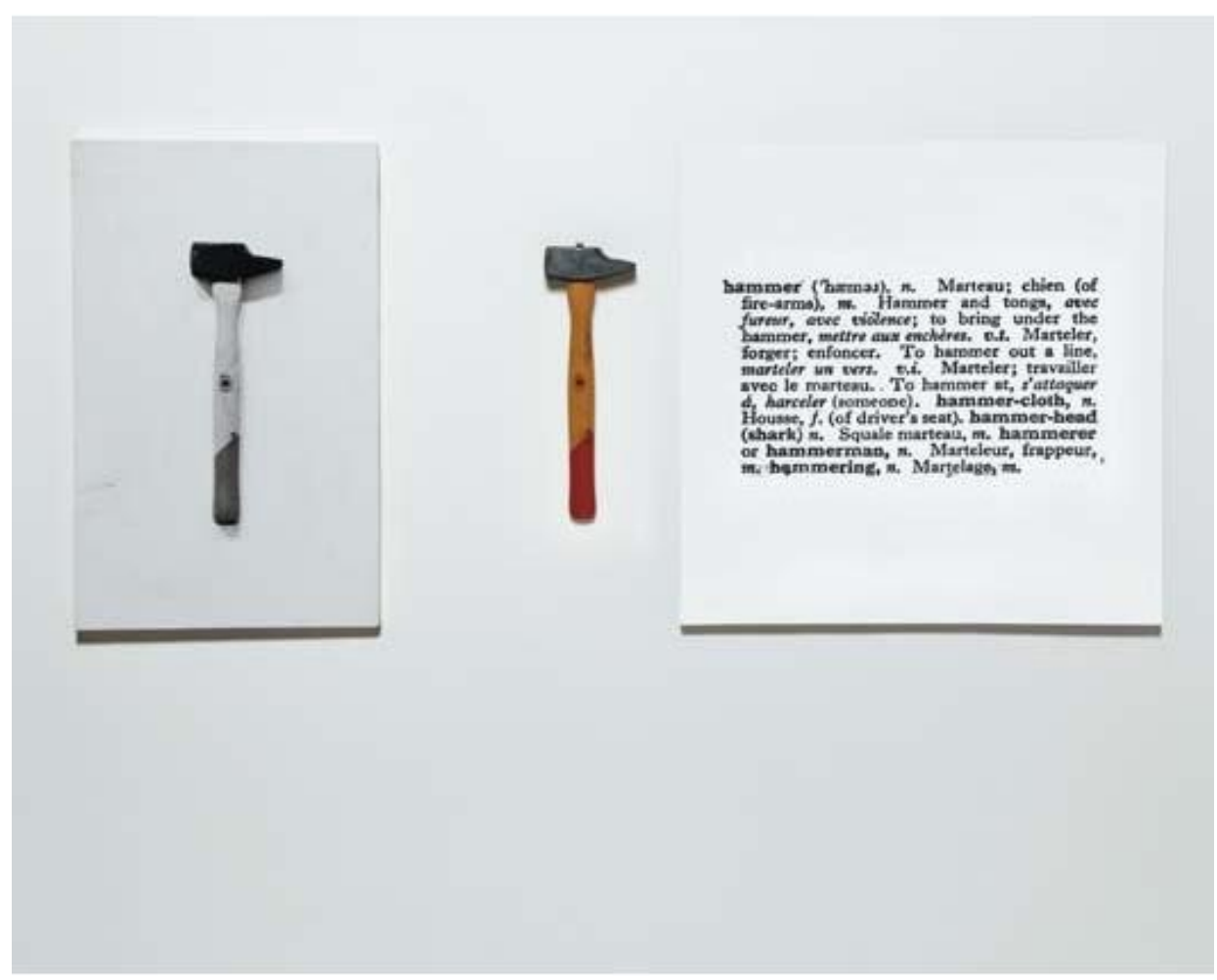

Resim 1: "Bir ve Üç Çekiç", 1965, çekiç, fotoğraf ve asetat, Foto - Panel: 65.4 x 40.6 cm, çekiç: 35.6 x 12.4 x $5.1 \mathrm{~cm}$, yazı paneli: 62.5 x $65.4 \mathrm{~cm}$. (Web 1)

\section{Joseph Kosuth: "Bir ve Üç Çekiç"}

\section{Künye ve Form - İfade Analizi}

ABD'li kavramsal sanatçı Joseph Kosuth'un (1945) 1965 yılında yaptı̆̆ı "Bir ve Üç Çekiç” adlı çalışması, çekiç, çekiç fotoğrafı ve basılı çekiç tanımı kullanılarak oluşturulmuştur. Çeşitli galeri ve sergilerde sergilenen bu yapıt Leo Castelli Gallery koleksiyonundadır. 
Yapıtın en sağında bir çekiç resmi, ortasında gerçek çekiç ve en solunda da basılı kâğıt üzerine bir çekicin sözlük anlamı belli bir düzen içinde yan yana duvara asılı olarak bulunmaktadır. Düzenlemenin ortasındaki gerçek çekiç ile să̆ yanındaki çekiç resminin boyutları eşittir. Çalışmada çekiç resmi ve yazı siyah beyaz iken çekiç nesnesi her çekiçte olduğu gibi ahşap rengi ile siyah renk içermektedir. En solunda da sözlükten alınmış çekici tanımlayan bir pafta belli bir düzen içerisinde yan yana asılıdır.

\section{Konu ve Anlatım Elemanlarının Analizi}

Joseph Kosuth'un önemli bir yapıtı olan "Bir ve üç çekiç" adlı yapıtın konusu endüstriyel bir malzeme olan çekiç aletinin gerçekliğidir. Sanatçıya göre dil de, sanat da soyutlamadır. Sanatçı dilbilimsel felsefenin etkisiyle sanatın varlığını dilbilimsel önermeye benzetmiştir. Dil ile sanat arasındaki benzerlikleri irdelemiştir. Sanatçı "Bir ve Üç Çekiç̧”te bir sözcüğün birden fazla anlamı olabileceğini ve belirli bir anlamın o sözcüğün kullanılışındaki bağlamla kazanılabilineceğini savunur. Örneğin Çekiç (Hammer) sözcüğü hem alet anlamında çekiç hem de yıkıcı kişi ya da kurumları tanımlamada kullanılmaktadır yani gerçek anlamını kullanıldığı bağlamın içinde bulmaktadır.

Çekiç İskandinav mitolojisinde gücü ve yıkıcılı̆̆ simgeler (web 1): İskandinavya'nın en güçlü tanrısı olan Odin'in oğlu Thor, Odin'den sonraki en güçlü tanrı olarak kabul edilir. Thor, kemer ve çekiç olmak üzere onu daha güçlü kılan iki sihirli nesneye sahipse de çoğu mitte çekiciyle ön plandadır. Thor bu çekiciyle fırtına ve yağmura yol açabiliyordu. Çekicin İskandinav mitolojisindeki "yıkıcı güç" anlamı ile yapıttaki kullanımı arasında bir bağ kurulabilir.

\section{Konu ve Anlatım Elemanlarının Estetik Analizi}

Yapıt yerleştirme esasına göre düzenlendiği için desen çizim esaslarına göre bir oluşum ve figür gözlenmemektedir. Ancak yapıta grafiksel açıdan baktığımızda kabaca üç parçalı bir ifade görmekteyiz. Üç parçaya ayrılan yapıtın en sağ ve en soldaki iki parçası aynı imgeyi göstermektedir. Yapıtta yer alan öğelere her hangi bir hareket verilmemiştir. Yapıtın en sağında yer alan ve asıl çekiç biçimine yakın boyutlardaki çekiç fotoğrafı lekesel özellikli ve üzerinde her hangi bir düzenleme yapılmadan kâğıda basılmıştır ve ortadaki gerçek çekiçle aynı düzleme asılı durumdadır. Soldaki asetat kâğıdı üzerine basılı olan siyah harfli çekici tanımlayan yazı aynı yüzeye monte edilmiştir.

Yapıta baktığımızda 1şığın yapıta yukarıdan dikey olarak vurduğu görülmektedir. Yapıtta bulundan çekiç fotoğrafında da 1şık galerideki gerçek çekice vurduğu gibi dikey olarak yukarıdan gelmektedir.

Çalışmada en solda bulundan yazılar ve en sağda bulunan çekiç resmi siyah beyaz bir görünüm sunarken, ortadaki çekiç renkli bir biçimde dikkatleri üzerine çekmektedir. Ortadaki gerçek çekicin sapının altı kırmızı renkte iken sapın geri kalanı ahşap rengindedir. Ortadaki Çekicin başındaki metal ise gri renktedir. Yapıt, boyları aynı olan bir üçlü (triptik) görünümü vermekte ve renk içeren öğe ortaya konularak bir odak noktası oluşturulmaktadır.

XX. yüzyılın ikinci yarısında üne kavuşan, Kavramsal sanatın önemli bir temsilcisi olan Joseph Kosuth özellikle dil bilimsel felsefeyi irdelemiştir. Yapıtlarında dil ve sanat arasındaki 
iliş̧kiyi irdelemiş, tüm sanatsal girişimlerin dilbilimsel doğasının anlaşılmasını amaçlamıştır (Fineberg, 2014, s. 325). Sanatı düşün olarak algılanmasını hedefleyerek bir önerme olarak ele almıştır.

\section{Form-İfadeye, Konu Anlatımına Dair Biçimsel ve Estetik Öğelerin Anlamlandırılması}

Kosuth yapıtlarında tamamen tekil nesneyi dışlayıcı çözümlemelere gitmiş ve sanat yapıtındaki geleneksel nesnel anlayışı tamamen ortadan kaldırarak salt düşünsel yaklaşımı ön planda tutmayı amaçlamıştır. Kosuth'un vardığı sanat yapıtına anti-estetiksel yaklaşımın temelinde Derida'nın yapısöküm felsefesi yatmaktadır (Şengül, 2013, s. 12). Yapısöküm felsefesinin yanı sıra Saussure'un dilmbilim alandaki görüşleri de Kosuth'un yapıtında etkilidir.

Joseph Kosuth'un yapıtında çekiç aracılığıyla dili kullanmasında bir diğer önemli etmen, Saussure'un dilbilim alandaki görüşleridir. Saussure'a kadar dil tarihsel bir süreç içinde gelişen, mantık kuralları içinde bir olgu olarak ele alınırken, Saussure dili başlı başına bir nesne olarak ele almıştır. Dil bir göstergedir. Kosuth'un yapmak istediği de budur. Çekicin bir yanına yazılı çekiç tanımı, diğer yanına da çekiç resmi koymakta ve her ikisinin de çekici tanımladığını belirtmektedir. Görselliğe dayalı resim bir göstergebilim içinde sanat nesnesi olabiliyorsa, yazı da aynı biçimde sanat nesnesi olabilmelidir. Her ikisi de aynı amaca hizmet etmektedir.

\section{Anlamlandırılan Biçimsel ve Estetik Verilerin Yorumlanması}

$\mathrm{Bu}$ yapıtın özgün niteliği sanat tarihi açısından köklü sorgulamalara ve yeniliklere kap1 araladığı ortadadır. Sanatçı çekiç fotoğrafı, çekiç ve çekiç tanımı ile sanat nesnesine dönüşen sanat yapıtlarını özgün bir biçimde ortaya koymaktadır. Sanatçı ilk kez dil bilimsel felsefenin etkisiyle sanat varlığını, dilbilimsel önermeyle benzeştirmiş, dil ile sanat arasındaki benzerlikleri irdelemiştir. İlk kez "düşün olarak sanat fikri” terimini kullanan Kosuth, sürekli olarak sanatın doğasını sorgulamıştır.

Kavramsal Sanat'ın öncülerinden olan ve çok yönlü bir kişiliğe sahip olan Kosuth'un psikoloji ve dil felsefesine ilgisi vardır. Sanatın doğasına ilişkin sorgulayıcı tutumu onu sanat tarihinin ayrıcalıklı sanatçılarından biri yapar. Sanatın doğasına ilişkin sorgulamalarını dil felsefesi doğrultusunda ortaya koymuştur. "Bir ve Üç Çekiç" adlı yapıtı da bu sorgulamaları doğrultusunda oluşturmuştur.

Joseph Kosuth'u ait olduğu sanat ortamı içinde değerlendirirsek onu Kavramsal Sanatın başlıca sanatçıları arasına koymalıyız. Sanatta biçimselliğe yöneltilen devrimci bir yaklaşım sergileyen Kosuth'un "Bir ve Üç Çekiç" adlı yapıtı kavramsal sanatın önemli yapıtları arasında saymamız gerekmektedir.

Joseph Kosuth'un bu yapıtı, çağdaşı olan yapıtların yanında dil felsefesini sanatın yapısını sorgulamada kullanma adına önemli bir yere oturtulmalıdır. "Bir ve Üç Çekiç" adlı yapıt, sanat tarihi içinde felsefe sanat ilişkisi bağlamında gerek sanatçısı, gerekse kendisi açısından önemli bir yerdedir.

\section{Yargı}

$\mathrm{Bu}$ yapıt sanatçının, anlamlı, düşündürücü, yenilikçi, etkili ve başarılı örneklerinden biridir. Bu yapıt, içeriğiyle, konusuyla ve anlamıyla içinde bulunduğu dönemde kendine özgün 
bir yer edinmiştir. Yapıt, çağdaşı olduğu diğer yapıtlar arasında dikkat çeken bir yerde durmaktadır. Sanat tarihi içinde kalıcı bir yeri hak etmektedir.

\section{Açıklama ve Tartışma}

"Bir ve Üç Çekiç" adlı yapıtın en önemli özelliği sanatla felsefenin önemli ölçüde iç içe geçmesi biçiminde özetlenebilir. Ana amacı sanatın gerek ve yeter koşullarını, doğasını ve ilişkili kavramları ortaya koymak olan sanat felsefesiyle (Mengüşoğlu, 2010, s.213; Albayrak, 2012, s.27; Caroll, 2012, s.25) de doğrudan ilişkili olan Kosuth'un bu yapıtı; sanat tarihinde kübizmin tam olarak yapamadığ 1 "zihinsel sanat" anlayışını hayata geçirmiştir. Zihinsel sanat, görünen dünyaya öykünmeye olan güvensizlikten temellerini almaktadır. Kavramsal sanat da öykünmeci sanattan kopan modern sanatın tekilliğine itiraz ederek onu felsefe ile bütünleştirme çabası içine girmiş̧ir.

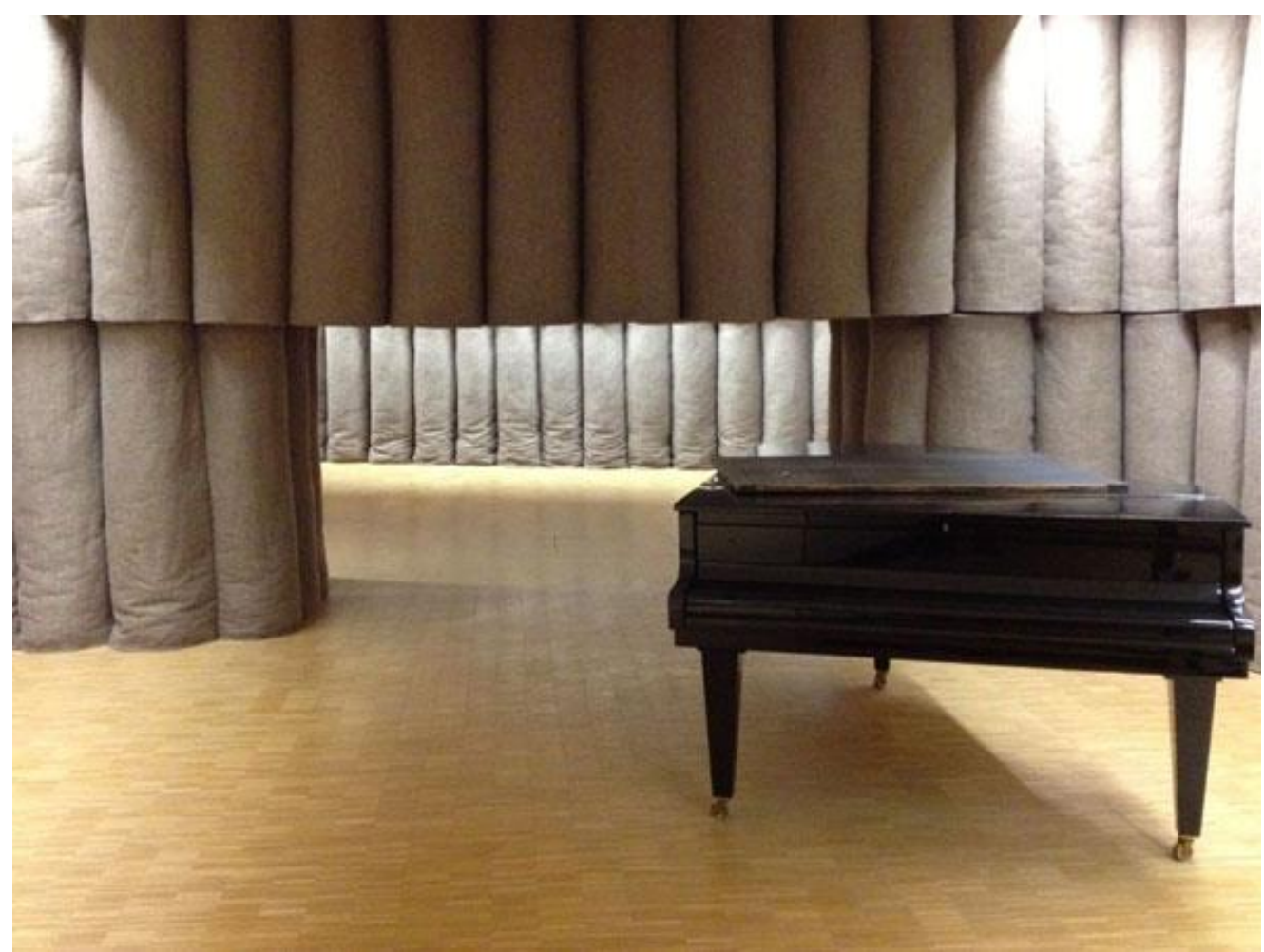

Resim 2: Joseph Beuys "Kötü Durum”, 1958 - 1985, keçe, piyano, karatahta, termometre, 310 x 890 x $1813 \mathrm{~cm}$.(web 2)

\section{Künye ve Form - İfade Analizi}

"Kötü Durum" adlı yapıtı; bir sanat galerisindeki iki odada; keçe, piyano, karatahta ve termometre ile meydana getirilmiştir. Yapıt, Londra Anthony d'Offay Galerisi'nde sergilenmiştir. Dikdörtgen biçimindeki galeride, iki ayrı mekânın duvarları, külrengi keçe ile rulo şeklinde yan yana dizilerek kaplanmıştır. Sanatçının kurguladığı mekânda keçe tomarları, 
duvarların yanlarına, iki sıra halinde odanın şekline uygun olarak sıralanmıştır. Beuys, üzerinde bir karatahtayla, bir termometre bulunan bir piyanoyu da galerinin tam ortasındaki boşluğa yerleştirmiştir. Mekânın tavanı beyaz bırakılmış, yerler ise parke kaplanmıştır. Sanatçının yapıtında odak piyanodur (Beyoğlu, 2019, s. 37).

Yapıttaki nesnelerin tümü düşünceye hizmet etmekte ve sanat yapıtını tekillikten çıkarıp tüm odaya ve izleyicinin zihnine yaymaktadır. Bu bağlamda yapıt; modern resimle başlayan “zihinsel sanat” özelliklerini bütünüyle göstermektedir.

\section{Konu ve Anlatım Elemanlarının Analizi}

Bu çalışma Alman sanatçı Joseph Beuys'un en önemli çalışması olarak kabul edilir. Bu bağlamda Lynton (2009)'da sanatçının düzenlemesini şöyle yorumlamıştır:

"Beuys'un düzenlediği galerideki iki ayrı mekân külrengi keçe tomarıyla kaplanmış ve üzerinde bir karatahtayla bir termometre bulunan bir piyanodan başka hiçbir eşyanın olmadığı bir yerdi. Keçe kaplı duvarlar mekâna belli bir ağırbaşl11ık veriyor, ayrıca sıcaklık, korunmuşluk ve Londra'nın merkezindeki gürültüye karşı bir yalıtım kazandırıyordu. Kapalı piyano, boş karatahta ve kimin için ne ölçtüğü bilinmeyen termometre de insanların özlemleriyle yeteneklerini ve bunların baskı altına alınışını dile getiriyordu" (Lynton, 2009, ss. 343 - 344).

\section{Konu ve Anlatım Elemanlarının Estetik Analizi}

Çalışmada bulunan malzemeler, sanatçının amacına uygun olarak belli bir düzen içinde yerleştirilmiştir. Keçe tomarları duvarların yanlarına, iki sıra halinde, sırasıyla bir düzlem boyunca odanın şekline uygun olarak sıralanmıştır. Lynton'un ifadeleri bağlamında keçe tomarlarıyla anlatılmak istenen şey; çevredeki bozuk düzenin insanın yeteneklerini, insanın korunma güdüsüyle bağlantılı olarak çevreden soyutladığg ifade edilebilir.

Çalışmada, keçenin şekli bozulmadan aslına bağlı kalınarak galerinin tavan kısmındaki spot lambanın 1şıklarıyla çalışmanın aydınlatılması sağlanmıştır. Kendine özgü fiziksel özellikleri koruyan, kül rengi bir keçe seçilerek çalışma oluşturulmuştur. Tavan rengi beyaz, piyano ve karatahta siyah renktedir.

\section{Form-İfadeye, Konu Anlatımına Dair Biçimsel ve Estetik Öğelerin Anlamlandırılması}

Joseph Beuys, bu çalışmasında, özgürlük ve yetenek arasındaki ilişkiyi irdelemiştir. Çalışmanın konusu bu bağlamda özgürlüğü kısıtlanan yeteneklerin düştüğü "kötü durum"dur. Beuys, bu yapıtını bu bağlamda "Kötü Durum” olarak adlandırmıştır. Bu sözcük ona insanlığın durumunu anımsatıyor; bu yolla sanatın insan yaşamındaki yerini ve ciddiyetini vurgulamıştır.

\section{Anlamlandırılan Biçimsel ve Estetik Verilerin Yorumlanması}

Eserin sanat tarihi içindeki yerine bakılacak olursa bütünüyle yeni ve özgün bir çalışma olduğu göze çarpar. Joseph Beuys, bu yapıtı ile birçok şeyi sorgulamaktadır. Sanatçı düşünce etkinliğini temel alarak sanat nesnesine yeni anlamlar yüklemiştir. Sanatçı oluşturduğu "Kötü Durum" adlı çalışmasıyla insanların galeri mekânındaki malzemeler üzerine düşünmesini amaçlamıştır. Malzeme seçimleri rastlantısal değildir. Kullandığı keçe uçak kazasından 
kurtulmasını sağlamıştır: Stalin'in zulmüne uğradıktan sonra Almanlara sempati besleyen göçebe bir tatar kabilesi tarafından kurtarıldığını ve ısı dengesini sağlamak için vücudunun yağla kaplandığını ve keçeyle sarıldığını ifade etmiştir. Bu bağlamda keçeye yalıtımsal bir anlam yüklenebilir. Ayrıca dış olumsuz etkenlerden bir koruma görevi de üstlenebilir: olumsuzluklar içeren çevreye karşı insanın kendini yalıtarak koruması (Fineberg, 2014, s. 218). Bunun yanında karatahta ise yine insanın yeteneklerini yansıtması çerçevesinde kapalı piyano ile birlikte değerlendirilebilir. Termometre ise sanatçının kurtulduğu kaza bağlamında simgesel olarak tutulan 1sıyı gösterdiği varsayılabilir. Bu da toplumdan korunmak amacıyla soyutlanan insanın korunma içgüdüsü ile bağlantılı olabilir.

Toplumsal sistemi sorgulayan ve her insanın yaratıcı yönüne vurgu yapan Beuys, herkesi yeni bir toplumsal sistem kurmaya çağırmış ve tüm yaratıcılığı engelleyen kültürel yapılara karşı koymaya teşvik etmiştir (Atakan, 2015, s. 34). Bu bağlamda söz konusu olan yapıt da bu bağlamda çözümlenmelidir: insan yaratıcılığına karşı olan olumsuz etmenler ve etkileri.

Sanatı insan düşüncesi ve eylemi olarak tanımlayan Beuys, "Kötü Durum” adlı yapıtıyla da insanları düşünmeye zorlamaktadır. Londra'nın kasvetli ve insanı kısıtlayan havasına ciddi bir eleştiri niteliği taşıyan bu yapıtı, onun dünya görüşünü de ortaya koymaktadır: insan yaratıcılığı ve özgürlüğü asla kısıtlanmamalı sanat da kısıtlamalara karşı durmalıdır.

Kavramsal sanatın önemli bir yapıtı olan "Kötü Durum” doğrudan insanın düşünce dünyasına seslenir. Bu durumda görsel estetik ikinci plandadır. Bu durum da sanatı nesne anlamında tartışmaya açmıştır.

Kökeni Duchamp'ın “Çeşme” adlı yapıtına dayanan bu anlayış düşünce merkezlidir. İkinci dünya savaşının yıkıcılığını da en açık bir biçimde yaşayan, savaşta ölümden dönen, Beuys sanatıyla da baskıcılığa ve tutuculuğa karşı durmuş, insanın özgürleşmesini savunmuştur (Fineberg, 2014, s.218-219).

"Kötü Durum", çağdaşı olan kavramsal yapıtlarla düşünsel açıdan benzer özellikler gösterir. İkinci Dünya Savaşı'nın yıkıcılığını ve acımasızlığını yaşayan kuşaklar; özgürlüklerin ve kolektif hakların ateşli birer savunucu olmuşlardır. Savaş sonrası dönemde de düşünsel protest yapıtlar ön plana çıkmıştır. Nietzsche felsefesinin de etkisiyle yıkılan batı uygarlığının temelleri sanatta da kendisini göstermiş ve bildiğimiz sanat yerini - örneğin tekil sanat nesnesini dışlayan - kavramsal sanat, minimal sanat gibi sanat akımlarına bırakmıştır. Dan Flavin'in minimal yapıtları ve Kosuth'un kavramsal yapıtları dönemin yıkıcılığını yansıtmaktadır.

\section{Yargı}

$\mathrm{Bu}$ yapıt, sanatçının dünya görüşünü etkili ve yaratıcı bir biçimde yansıtmaktadır. Sanatçının yaşanmışlıklarını ve ideolojisini harmanlayarak izleyiciye aktarmaktadır. Bu yapıt, ait olduğu sanat ortamında etkili ver kalıcı bir yere sahiptir. Çağdaşı olan yapıtlar arasında gerek sanatsal yapısı, gerek de özgünlügü bakımından kendine dikkat çekici bir yer edinmiştir. Bu yapıt sanat tarihi içinde önemsenmesi gereken bir yerdedir.

\section{Açıklama ve Tartışma}


"Kötü Durum" adlı yapıt, kavramsal sanatın "zihinsel” özelliklerini göstermektedir. İnsanın yaratıc1lıklarına, toplumsal normların verdiği olumsuz etki ve sanatın gücünün konu alındığı yapıt; yine tüm kavramsal sanat yapıtlarında olduğu gibi felsefe ile iç içedir denilebilir.

Sanat felsefesinin "Bir ve Üç Çekiç" adlı yapıttaki görselleşmesinin bu yapıtta da meydana geldiği söylenebilir: düşüncenin ve felsefenin görselleşmesi. Kavramsal sanatla gelişen bu yeni durum, sanatı salt güzellikle ilişkilendiren görüşleri tamamen geçersiz kılmış ve sanatın tanımlarının güncellenmesine neden olmuştur.

\section{SONUÇ}

Çağdaş sanat eleştirisinde nitelikli yapıtları, niteliksizlerden ayırmak sanatın geleceğinin sağlam temellere oturtulması bağlamında çok önemli bir yer tutar. Nitelikli yapıtların belirlenebilmesi, çağdaş sanat içinde, sanat kavramının diri ve canlı tutulmasının gereğidir. $\mathrm{Bu}$ yolla sanat, hem sağlıklı bir yol izleyecek hem de yıkıcılık işlevinden sıyrılabilecek, toplumun aydınlatılmasında önemli olan rolünü oynayabilecektir. Sanatın toplumda öncü rolünü oynayabilmesi için her şeyden önce kendi içinde bütünlüklü, tutarlı, ilerici niteliklere sahip olması gerekmektedir. Sanatın toplumun her alanda öncü kılacak özelliklere sahip olmasının birinci koşulu, sanat eleştirisi süzgecinden geçmesi ve bu vasıtayla yönünü bulmasıdır.

Nitelikli yapıtları, niteliksizlerden ayırmanın yaşamsal yöntemi olan sanat eleştirisi, sanat kavramı için hayatiyet arz eder. Ancak bu noktada sanat eleştirisi kavramına da değinmek yerinde olacaktır. Sanat eleştirisi ancak ve ancak akademik anlayış ile uygulanırsa geçerli olur, amacına ulaşır. Bu akademik anlayış ise; sanat eleştirisinin nesnel, metodolojik, bilimsel, bir nitelik taşıması anlamındadır. Bu bağlamda bu çalışmada "Bir ve Üç Çekiç" ve "Kötü Durum" adlı yapıtlar bir metodolojiye oturtularak çözümlendi.

Akademik ve Disiplinlerarası Yeni Sanat Eleştirisi Kuramı kullanılarak çözümlenen "Bir ve Üç Çekiç" ve "Kötü Durum" adlı yapıtlardan ilkinin ortaya koyduğu anlam, sanat ve dil arasındaki ilişki iken ikinci yapıtın ortaya koyduğu anlam ise özgürlüktür. Söz konusu yapıtlar bu anlamı insan zihninde oluşturmak amacıyla yapılmıştır. Bu yapıtların bütünüyle maddesel kısıtlamalardan kurtulma ereğiyledir denilebilir. Bu bağlamda sanat yapıtlarının felsefe ile olan ilişkilerine maddesel eksiklikler girmemektedir. Çünkü sanat yapıtı bu bağlamda insan zihnine de tam anlamiyla girmektedir.

Çalışmada nesnel ve disiplinlerarası bir eleştiri yönteminin çağdaş sanata uyarlanmasına çalışılmıştır. Sonuç olarak çağdaş sanatın önemli bir aşaması olan kavramsal sanatın zihinselliği, dil ile bağlantısı ve protest yönü ortaya konulmuştur.

\section{KAYNAKÇA}

Akkaya, T. (2014). Akademik ve Disiplinlerarası Yeni Sanat Eleştirisi Kuramı. İstanbul: Arkeoloji ve Sanat.

Albayrak, M. (2012). Estetik'in Serüveni. Ankara: Akçağ Yayınları.

Antmen, A. (2010). 20. Yüzyıl Batı Sanatında Akımlar. İstanbul: Sel.

Artan Oskay, B. (2018). 1960 Sonrası Kavramsal Sanatının Günümüz Resim Sanatına Etkileri. İdil Sanat ve Dil Dergisi, 47, 803 - 809. 
Atakan, N. (2013). Sanatta Alternatif Arayışlar. İzmir: KaraKalem.

Beyoglu, A. (2019). Sanatta mekan kurgusu bağlamında Joseph Beuys yapıtları. YEDİ: Sanat, Tasarım ve Bilim Dergisi, Kış 2019 (21), s. 33-41.

Carroll, N. (2012). Sanat Felsefesi Çağdaş Bir Giriş. Ankara: Ütopya.

Danto, A. (2014). Sanat Nedir. Zeynep Baransel (Çev.). İstanbul: Sel.

Erden, E. O. (2016). Modern Sanatın Kısa Tarihi. İstanbul: Hayalperest.

Eroğlu, Ö. (2015). Modern Sanat. İstanbul: Tekhne.

Fineberg, J. (2014). 1940’tan Günümüze Sanat. Simber Atay (Çev.). İzmir: KaraKalem.

Harrison, C. Wood, P. (Ed.) (2011). Sanat ve kuram 1900 - 2000 değişen fikirler antolojisi. Sabri Gürses (Çev. ). İstanbul: Küre.

Hopkins, D. (2018). Modern Sanattan Sonra. Firdevs Candil Erdoğan (Çev.). İstanbul: Hayalperest.

Lynton, N. (2009). Modern Sanatın Öyküsü. Sadi Öziş, Cevat Çapan (Çev.). İstanbul: Remzi.

Mengüşoğlu, T. (2010). Felsefeye Giriş. İstanbul: Remzi Kitabevi.

Şengül, E. (2013). Dilbilimsel Kavramsalcilikta Anti - Görsel Deneyim Ve Anti - Estetik Haz: Joseph Kosuth. İdil Sanat ve Dil Dergisi, 8, 1-13.

Web 1: https://www.papiroom.net/525053505452_mitoloji--mistik-oyku-ornekleri (Erişim Tarihi: 08.12.2019)

Web2:https://images.squarespacecdn.com/content/v1/51a62292e4b07c0410ac1029/1400001033 811-O8J0K3LS51QHIRZ009F/ke17ZwdGBToddI8pDm48kJbosy0LGK_KqcAZRQ_Qph1ZwzPPgdn4jUwVcJE1ZvWQUxwkmyExglNqGp0IvTJZUJFbgEXRK3dMEBRBhUpyRoXPauM_ hSH3XAFUMH3fmO1jdMVKkonRM0cGdyUtJRnZ7FnwXS6LE3CJOOwAGcs0/piano.jpg (Erişim Tarihi: 22.12.2019). 